\title{
Human Rights of the Disadvantaged Groups in Armenia and Russia
}

\section{Aram TERZYAN*}

This study focuses on some of the human rights of disadvantaged groups in Armenia and Russia.

According to widely - held beliefs, today Russia is more repressive than it has ever been in the post-Soviet era. ${ }^{\mathrm{i}}$

As a matter of fact, Russia's post-soviet transition has been marred by a series of authoritarian malpractices, ranging from centralization and personalization of power to extensive crackdown on civil liberties and political freedoms. ${ }^{\text {ii }}$ What makes Russia stand out from other post-Soviet countries is that the combination of historical conditions that had created a strong anti-communist consensus in most of Eastern Europe had not taken shape in Russia. Clearly, it would be unrealistic for Russians to treat the Soviet system as an imposition on them by a foreign power or see it as an obstruction to independence. As a result, there was a lack of a consensus at the elite and popular levels about the desired character of political and economic transformation. ${ }^{\text {iii }}$

There is a broad consensus among the students of Russian politics that the Russian regime centered around "Putinism" is as a form autocratic rule that is personalistic, conservative and populist. $^{\text {iv }}$

Overall, the state of human rights in Russia has been on severe during Putin's presidency, with the rights to freedom of expression, association and peaceful assembly consistently restricted, in law and practice. ${ }^{\mathrm{N}}$

The long list of human rights abuses in Russia includes arbitrary arrest and detention; extrajudicial killings; pervasive torture by law enforcement authorities; life-threatening conditions in prisons; political prisoners; arbitrary interference with privacy; violence against journalists; severe suppression of the right of peaceful assembly; severe restrictions of religious freedom; severe limits

\footnotetext{
* Aram TERZYAN, PhD, is the research director of the Center for East European and Russian Studies of Eurasia Institutes, USA, e-mail: a.terzyan@eurasiainstitutes.org .
} 
on participation in the political process, including restrictions on opposition candidates' ability to seek public office; systematic government corruption; trafficking in persons; and crimes involving violence or threats of violence against persons with disabilities, LGBTI persons, and members of ethnic minorities. $^{\text {vi }}$

viiThe 2012 Foreign Agent Law has been a huge blow to the NGOs free and independent activities in Russia. According to its provisions, organizations engaging in political activity and receiving foreign funding must register as foreign agents, even if the foreign funding they receive does not actually pay for political activities. ${ }^{\text {viii }}$

As a result, the NGOs focusing more on Western ideas, such as LGBT rights get labelled as "foreign" agents. These NGOs encounter a very hostile environment, and face fines and potential shutdowns. ${ }^{\text {ix }}$

This picture has much to do with the Kremlin's emphasis on the necessity of defending traditional values as opposed to those of liberal democracy.

To justify massive violations of human rights, the Kremlin has consistently strived to delegitimize the idea of liberal democracy itself, labelling it subversive and alien to the Russian national character. ${ }^{\mathrm{x}}$

The Russian president tends to contend that the ideology underpinning Western democracies for decades has "outlived its purpose". Thus, "the liberal idea has become obsolete. It has come into conflict with the interests of the overwhelming majority of the population". ${ }^{\mathrm{i}}$

Liberal democracy has been invariably associated with the acceptance of homosexual rightshailed by the Russian president as a "genderless and fruitless tolerance" that allows "good and evil" to be valued as equal. ${ }^{\text {xii }}$ Moreover, the West has been regarded as a purely LGBT-promoting community that endangers national identities and traditional values in post-Soviet countries and beyond. ${ }^{\text {xii }}$

To prevent all these from happening, Putin has positioned Russia as a counter-hegemonic force opposed to the West's "crackdown" on conservative values and even world's last bastion of traditional values, characterized by its rejection of revolutions, homosexuality and feminism. ${ }^{\text {xiv }}$

Apart from encouraging homophobia, this rhetoric has led to the further misrepresentation of liberal democracy -often contrasted with Russian "sovereign democracy." Remarkably, the narratives that underpin Putin's discourse have proven popular with the Russian population. According to a survey conducted by the state-run Russian Public Opinion Research Centre, nearly 
two-thirds of Russians believe that homosexuals are conspiring to subvert the country's traditional values. ${ }^{\mathrm{xv}}$ Moreover, they believe in the existence of an organization that strives to destroy Russian spiritual values through imposing radical minority norms on the country's majority.

As a matter of fact, the Russia's closest allies, including Armenia, have largely met the requirements of its 'conservative alliance' by largely discriminating against sexual minority groups.

Despite Armenia's approval of the UN Declaration on Sexual Orientation and Gender Identity in 2008, the country is one of the most homophobic in Europe. According to ILGAEurope's Rainbow Europe country ranking, Armenia occupies practically the penultimate place, 47 th out of 49 , in terms of respect for LGBT+ rights. And according to a survey by the Pew Research Centre, $95 \%$ of Armenians under the age of 35 disapprove of gay marriage. ${ }^{\text {xi }}$

Not surprisingly, according to the report on the situation for LGBT persons in Armenia, conducted by ILGAEurope, the public attitude towards the LGBT community is highly hostile. According to their assessment, the word 'homosexual' is used as an insult. ${ }^{\text {xvii }}$ The difficulties for LGBT persons who wish to come out are compounded by negative societal attitudes. A representative of the prosecutor's office describes the situation this way: "LGBT persons exist, but not many in the open. They are hiding, though the general attitude is not negative, they are just seen to be ill people who are unfortunate to be born like that." xviii

As a result, violence, and discrimination against LGBT people or those who are deemed to represent that community are widespread. Namely, in 2012 the only gay club in Yerevan, DIY was burned down, and the arsonist, two Iranian-Armenian brothers, received a suspended sentence. The episode triggered an attack on the LGBT+ community by pro-government media, and a ruling Republican Party MP described the attack as "proper and justified". xix

That same year, the LGBT community attempted to hold a Diversity March, but it was broken up by supporters of "traditional values". In 2014, the popular Iravunk newspaper printed a list of 40 Facebook users which, it claimed, "serve the interest of the international homosexual lobby”. Since then, Armenia's LGBT+ community has conducted no open events or activities. ${ }^{\mathrm{xx}}$

At the same time, Armenia voted to join the Eurasian Economic Union, and continued to draw closer to Moscow. And since Russia passed what became known as its "Gay Propaganda Law" in 2013, incidents of homophobia-instigated violence in Armenia have been on the 
increase. ${ }^{\mathrm{xxi}} \mathrm{A}$ well-informed observer notes that "People here watched what people were telling them on TV and did the same - Armenians have always followed Russia's lead."'xxii

Political leaders often openly support right-wing organizations and their members. For example, former Vice President of the Armenian Parliament, Eduard Sharmazanov, supported a nationalist attack on the DIY club, whilst another Parliament member, Artsvik Minasyan said that the attackers acted to protect national values and national ideology. ${ }^{\text {xiii }}$

Many gay and trans activists were optimistic that the country's deep-seated homophobia would start to decline after mass street protests in April 2018 ousted long-time leader Serzh Sargsyan. Less than a month after parliament elected Pashinyan as acting prime minister on May 8, a group of 30 people attacked nine LGBT rights activists in the southern village of Shurnukh. ${ }^{\text {xxiv }}$

The perpetrators were given a collective pardon and law enforcement authorities closed the case. $^{\mathrm{xxv}}$

The situation came to a head in April 2019, when openly transgender Lilit Martirosyan spoke in the Armenian parliament about the widespread abuses facing LGBT people. Her speech was followed by death threats, while prompting many nationalist and conservative groups as well as religious figures, to gather in front of parliament to protest LGBT rights. ${ }^{\text {xxvi }}$

Societal discrimination based on sexual orientation and gender identity negatively affected all aspects of life, including employment, housing, family relations, and access to education and health care. ${ }^{\text {xxvii }}$ Anti-LGBT sentiments and calls for violence have not subsided since the 2018 "Velvet Revolution". Rather, many politicians and public figures tend to use anti-LGBT rhetoric, often positioning LGBT persons as a "threat to national security." "xxviii

Along with LGBT community, it has not been uncommon for the disabled to experience discrimination and mistreatment both in Russia and Armenia

According to the UN Convention on the Rights of Persons with Disabilities, disabled persons are those who have "long-term physical, mental, intellectual or sensory impairments", which might prevent them from fully and effectively participating in societal life. ${ }^{\text {xix }}$ The main objective of the Convention is "to promote, protect and ensure the full and equal enjoyment of all human rights and fundamental freedoms by all persons with disabilities, and to promote respect for their inherent dignity". ${ }^{\mathbf{x x}}$ As a UN member country, Russia signed the Agreement on September 24, 2008. However, as aptly noted by the Foreign Minister of Russia Sergey Lavrov, despite measures 
taken by the government to protect the rights of disabled persons, a myriad of issues remains unaddressed (Paramonova, 2008). ${ }^{\text {xxi }}$

More than a decade has passed since the ratification of the document by the Russian Federation, but the state of disability human rights in Russia remains of serious concern. There is ample evidence of severe human rights violations on social media and beyond. To give an idea of the scale of discrimination and violation, it is noteworthy, that as posted on social media by a resident of Zelenodolsk, her son, 2nd group disabled, was taken off the last intercity bus (Inkazan, 2020). ${ }^{\text {xxxii }}$ Another person was killed, while trying to protect a disabled person from violent attack by two assaulters (Sport24, 2020). ${ }^{x x i i i}$ According to another report, the entrance examination committee of Moscow City Government University of Management rejected a student's application because of her disability (Sher, 2020). ${ }^{\text {xxxiv }}$

Not surprisingly, people with disabilities file over 1000 complaints to the High Commissioner for Human Rights in the Russian Federation, pertaining to the procedure of disabled person status recognition; reassessment of disability status; reassessment of disability causes, as well as to arbitrary changes of individual rehabilitation programs, etc. ${ }^{\mathrm{xxv}}$

The welfare of families having people with disabilities is relatively lower than other families in Russia as a whole. The average monthly income of the first group is approximately 37 thousand rubles, which is 4 thousand rubles lower than for other families. Simultaneously, studies show that the costs of treatment and fulfillment of the needs of disabled people are higher than among ordinary Russians. From the perspective of consumption, studies show that approximately $30 \%$ of families having disabled persons barely have enough money for food and clothing (28\%), while among ordinary families this indicator accounts for $-21 \%{ }^{\text {xxvi }}$. This prompts to posit, that there is considerable imbalance of both income and expenditure among families comprised of disabled members.

Unlike western societies, that tend to treat disabled persons as equal members of the society, discrimination against and mistreatment of the disabled across Russia has not been uncommon (Puzanova, 2017). ${ }^{\text {xxvii }}$

According to public surveys, while it is not uncommon for Russians to empathize with the disabled, they do not tend to go the extra mile and assist them in the form of donations, etc. (NAFI, 2019). Moreover, considerable part of Russians avoids having disabled people around. More 
specifically, every fourth person (25\%) tries to avoid communication with the disabled; $40 \%$ believe that the disabled prefer to communicate with the disabled like them, while $48 \%$ of respondents said that they would not build a family with the disabled (NAFI, 2019).

As for Armenia, studies show, that among other groups, HIV-positive people face extreme health care hardships and rampant discrimination. More specifically, a survey suggests that out of 120 dental clinics, "more than a hundred" declined services to patients with HIV, but would accept patients with Hepatitis C. ${ }^{\text {xxxviii }}$ Between 1988 and February 28, 2019, 3,409 cases of HIV infection were registered in Armenia, including 429 in 2018. ${ }^{\text {xxix }}$

Organizations advocating the rights of those with HIV/AIDS state that such wariness among doctors toward HIV-positive patients is nothing new. Issues arise not only when seeking medical treatment, but also when enrolling HIV-positive children in schools or kindergartens. In 2012, the ombudsman's office tried unsuccessfully to enroll an HIV-positive child, the daughter of an HIVpositive parent, into a public kindergarten or non-profit daycare center. Out of 18 such institutions approached, most refused to take the child because of her disease; the rest claimed that they had no space. Eventually, the child was sent to a state-run orphanage. ${ }^{\mathrm{xl}}$

"In people's perception, HIV is a death sentence, and they are afraid of anything related to HIV," said Harutiunian. ${ }^{\text {xli }}$ Some observers contend that "The problem is in people's minds, that's why there is discrimination..." ${ }^{\text {’lii }}$

The survey was conducted among 74 HIV-positive people shows that around 76,2\% of them said that they had been subjected to discrimination by medical institutions and denied proper medical care. .liii $^{\text {lii }}$

It is not uncommon for HIV-positive and other disabled people to fear ostracism and harsh discrimination. As a result, these people are forced to hide the disease, with little to no faith in Armenian health care system. ${ }^{\text {xliv }}$

Some end up unemployed, while others are forced to flee the country after years of having to pass through a myriad of crucibles and ordeals. ${ }^{x l v}$

\section{References}

\footnotetext{
${ }^{\mathrm{i}}$ Human Rights Watch (2019), Russia (retrieved from https://www.hrw.org/europe/central-asia/russia ).

ii Freedom House: Russia (2020). (retrieved from https://freedomhouse.org/country/russia/nationstransit/2020).
} 
${ }^{i i i}$ Evans, A. B. (2011), The Failure of Democratization in Russia: A Comparative Perspective, Journal of Eurasian Studies, 2(1), p. 47.

${ }^{\text {iv }}$ Fish, M. S. (2017), The Kremlin Emboldened: What Is Putinism? Journal of Democracy, 28(4), p. 61.

$v$ Amnesty International (2019). Russian Federation 2019 (retrieved from https://www.amnesty.org/en/countries/europe-and-central-asia/russian-federation/report-russianfederation/ ).

vi Department of State (2019). Russia 2019: Human Rights Report (retrieved from https://www.justice.gov/eoir/page/file/1258581/download ).

viii Freedom House (2012). Factsheet: Russia's NGO Laws (retrieved from https://freedomhouse.org/sites/default/files/Fact\%20Sheet_0.pdf ).

${ }^{\text {ix }}$ Dufalla, J. (2010). Non-Governmental Organizations in Russia: Adapting for Success, Vestnik. The Journal of Russian and Asian Studies, (15), pp. 1-22

${ }^{\mathrm{x}}$ Finkel, E. and Brudny, Y. M. (2012), Russia and the Colour Revolutions, Democratization, 19(1), p. 15.

xi Putin (2019). Vladimir Putin says liberalism has 'become obsolete' (retrieved from https://www.ft.com/content/670039ec-98f3-11e9-9573-ee5cbb98ed36).

xii Terzyan (2020). Towards a Monarchical Presidency in Russia, New Eastern Europ (retrieved from https://neweasterneurope.eu/2020/04/17/towards-a-monarchical-presidency-in-russia/ ).

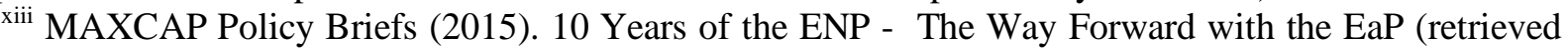
from http://userpage.fu-berlin.de/kfgeu/maxcap/sites/default/files/sites/default/files/policybriefs/maxcap_policy_brief_01.pdf ).

${ }^{x i v}$ Orlova, A. V. (2018), Russian Politics of Masculinity and the Decay of Feminism: The Role of Dissent in Creating New Local Norms, Wm. \& Mary J. Race Gender \& Soc, 25, pp. 59-86.

${ }^{x v}$ Terzyan (2020), Ibid.

${ }^{x v i}$ Open Democracy (2019). Armenia's Velvet Revolution is yet to bring change for the country's LGBT community (retrieved from https://www.opendemocracy.net/en/odr/non-sexual-revolution-armenia-en/ ).

xvii Study on Homophobia, Transphobia and Discrimination on Grounds of Sexual Orientation and Gender Identity Sociological Report: Armenia (retrieved from https://www.coe.int/t/Commissioner/Source/LGBT/ArmeniaSociological_E.pdf).

xviii Ibid.

xix Open Democracy (2019), Ibid.

${ }^{x x}$ Ibid.

${ }^{x x i}$ Human Rights Watch (2018). No Support Russia's "Gay Propaganda" Law Imperils LGBT Youth (retrieved from https://www.hrw.org/report/2018/12/11/no-support/russias-gay-propaganda-law-imperilslgbt-youth\#).

xxii Open Democracy (2019), Ibid.

xxiii Armenian Weekly (2012). Hate Crime Targets Gay Friendly Bar in Yerevan, MPs Bail out Assailants (retrieved from https://armenianweekly.com/2012/05/15/hate-crime-targets-gay-friendly-bar-in-yerevanmps-bail-out-assailants/).

${ }^{x x i v}$ Reuters (2019. Armenia's LGBT+ community still waits for change one year after revolution (retrieved from https://fr.reuters.com/article/us-armenia-lgbt-politics-idUSKCN1S300H ).

${ }^{x x v}$ Ibid.

${ }^{x x v i}$ Ibid.

${ }_{x x v i i}$ Department of State (2019). Country Reports on Human Rights Practices: Armenia (retrieved from https://www.state.gov/reports/2019-country-reports-on-human-rights-practices/armenia/).

xxviii Terzyan, A. (2020). Political Freedoms and Human Rights in Eurasian Economic Union Countries: The Cases of Russia, Armenia, Belarus, and Kazakhstan, 2020, no. 2, Eurasian Affairs Research Papers, pp. 11-12.

${ }^{x x i x}$ United Nations. (2016). Convention on the Rights of Persons with Disabilities and Optional Protocol (retrieved from https://www.un.org/disabilities/documents/convention/convoptprot-e.pdf ). 
${ }^{\mathrm{xxx}}$ Ibid.

${ }^{x x x i}$ Paramonova, M. (2008). Russia signed the UN Convention on the Rights of Persons with Disabilities (retrieved from https://humanrightshouse.org/articles/russia-signed-the-un-convention-onthe-rights-of-persons-with-disabilities/).

xxхіi Inkazan. (2020). В Казани Прокуратура Проверяет Информацию о Снятии Полицией Инвалида с Автобуса. (In Kazan, the Prosecutor's Office Checks Information about the Removal of a Disabled Person from the Bus by Police) (retrieved from https://inkazan.ru/news/city/10-08-2020/v-kazaniprokuratura-proveryaet-informatsiyu-o-snyatii-politsiey-invalida-s-avtobusa) .

xхxiii Sport24. (2020). Боксер Старцев Убил Мужчину, Который Пытался Заступиться за Избиваемого Инвалида (Boxer Startsev Killed a Man who Tried to Stand up for a Beaten Disabled Man) (retrieved from https://sport24.ru/news/mma/2020-07-28-v-barnaule-bokser-udarom-v-golovu-ubilmuzhchinu-kotoryy-pytalsya-zastupitsya-za-izbivayemogo-invalida) .

xхxiv Sher, М. (2020). "Кто с ней Возиться Будет?": как Абитуриентку с Инвалидностью

Отговаривали от Обучения в Вузе. "Who will Mess with her?": how an Applicant with a Disability was

Dissuaded from Studying at University (retrieved from https://russian.rt.com/russia/article/775605abiturient-invalidnost-vuz-otkaz ).

${ }^{x x x v}$ UN Human Rights Office of the High Commissioner. (2018). Report on the Rights of Persons with Disabilities to the Highest Attainable Standard of Physical and Mental Health (retrieved from https://www.ohchr.org/EN/Issues/Disability/SRDisabilities/Pages/StandardOHealth.aspx).

xxxvi The Levada Center. (2019). Отношение Россиян к Людям с Ограниченными возможностями Здоровья. (Attitude of Russians to People with Disabilities) (retrieved from https://komitetgi.ru/upload/iblock/b73/\% pdf ).

xxxvii Puzanova, Z. (2017), Ibid.

xxxviii Jam News (2019). Armenia: HIV patients face discrimination - from doctors (retrieved from https://jam-news.net/armenian-hiv-patients-suffer-discrimination-at-doctors-hands/).

xxxix Ibid.

${ }^{x l}$ Eurasianet (2015). Armenia: HIV/AIDS Patients Struggle with Rampant Discrimination (retrieved from https://eurasianet.org/armenia-hivaids-patients-struggle-with-rampant-discrimination).

xli Jam News (2019), Ibid.

xlii Ibid.

xliii Ibid.

xliv Sahakyan, A (2016). Arman Sahakyan introduced the discrimination against people living with HIV in Armenia (retrieved from https://old.ngngo.net/hiv-5/).

xlv Ibid. 